\title{
Geoelectric Characterization of Aquiferous Units and its Implication on Groundwater Potential of Owo, Southwestern Nigeria
}

\author{
Ogundana A. $\mathbf{K}^{1, *}$, Talabi A. $\mathbf{O .}^{2}$ \\ ${ }^{1}$ Department of Geology, Afe Babalola University, Ado-Ekiti. \\ ${ }^{2}$ Department of Geology, Ekiti State University, Ado-Ekiti \\ *Corresponding author: dejiogundana@gmail.com
}

Received March 19, 2014; Revised April 25, 2014; Accepted May 15, 2014

\begin{abstract}
Geophysical study of the North-eastern part of Owo was conducted to investigate the geoelectric characteristics of its aquiferous units and its implication on groundwater potential of the area. Vertical electrical sounding method was employed and Schlumberger configuration was adopted. Thirty-two points were sounded along three different sections of the town namely; Idasen, Okedogbon and Express (Figure 1). Six different subsurface lithologic units were established namely; lateritic topsoil, clay, sand, quartzite, weathered/fractured basement and, basement. The curve types range between simple H, K, HA, HK, KH to complex, HKH, KHA and KHK. The topsoil, clay, sand and weathered basement materials are characterised with relatively low resistivity values while the quartzite ridge materials are characterized with high resistivity values. The average resistivity and thickness values for the topsoil are $220 \Omega \mathrm{m}$ and $2.0 \mathrm{~m}$ respectively. Clay was encountered across Okedogbon and Express area of the town and the average resistivity and thickness values of $34 \Omega \mathrm{m}$ and $6.0 \mathrm{~m}$ respectively. Sand was encountered across the entire study area with average resistivity and thickness values of $115 \Omega \mathrm{m}$ and $11.0 \mathrm{~m}$ respectively. Quartzite was encountered in all the locations with average resistivity and thickness values of $611 \Omega \mathrm{m}$ and $11.0 \mathrm{~m}$ respectively. Weathered/fractured basement was encountered across the three sections with average resistivity and thickness values of $86 \Omega \mathrm{m}$ and $12.0 \mathrm{~m}$ respectively. Basement is relatively deep in the study area and the average resistivity and depth values to the top of basement are $878 \Omega \mathrm{m}$, and $24 \mathrm{~m}$ respectively. Overburden thickness was established across the area with an average value of $20 \mathrm{~m}$. The overburden materials with the fractured basement constitutes aquiferous units within the study area though the sand and weathered basement units are largely responsible for the groundwater potential. The groundwater potential of the area is moderate with Express area having the highest potential.
\end{abstract}

Keywords: geoelectric characteristics, groundwater potential, lateritic topsoil, lithologic variation and aquiferous units

Cite This Article: Ogundana, A. K, and Talabi A. O., "Geoelectric Characterization of Aquiferous Units and its Implication on Groundwater Potential of Owo, Southwestern Nigeria." American Journal of Water Resources, vol. 2, no. 2 (2014): 37-40. doi: 10.12691/ajwr-2-2-2.

\section{Introduction}

Owo, a town in Ondo state, southwestern Nigeria, is an agrarian community with some commercial activities. The north-eastern part of the town is undoubtedly the commercial nerve centre of the community in which most commercial activities revolve.

Presently, the community depends on rainwater, surface water and groundwater for its water supplies and the daily demand for potable water is yet to be met. Most of the establishments in this area spent fortunes in purchasing water to meet their basic water requirements.

The community is located on a quartzite ridge in a complex basement terrain where occurrence of groundwater in recoverable quantity as well as its circulation is controlled by geological factors.
(Olorunfemi and Fasuyi (1993) upheld that most often, the occurrence of groundwater in the Basement Complex terrain is localized and confined to weathered/fractured zones. Groundwater potential in Owo is governed by the amount of precipitation and the recharge area of the aquifer, the extent of weathering within the basement and the presence of fractures, cracks, joints and fissures within the basement rocks. The combination of thick, porous weathered basement and the underlining network of deep fracture zones constitute the aquiferous units within this area.

Olayinka and Olorunfemi (1992) emphasized the need to conduct a surface geophysical survey such as Vertical Electrical Resistivity Sounding in identifying the localized aquiferous zones before siting boreholes.

Electrical resistivity method has been used extensively in groundwater investigation especially in the basement 
complex terrains (Grant and West, 1965, Olorunfemi and Olorunniwo, 1985. Olorunfemi, 1990. Olorunfemi and Olayinka, 1992). The method is commonly used in getting detailed information about hydrogeological settings for groundwater.

This study therefore aims at assessing the geoelectric characteristics of the aquiferous units and its implication on groundwater potential of the area with attention on the delineation of the fracture system, overburden thickness and lithological variation across the terrain.

\section{Location and Geology of the Study Area}

Owo is in southwestern Nigeria, at the southern edge of the Yoruba Hills, and at the intersection of roads from Akure, Kabba, Benin City, and Siluko. Owo is situated halfway between the towns of Ile Ife and Benin City (Figure 1). The terrain in the study area is moderately undulating, with topographic elevation ranging from 200 $\mathrm{m}$ to $360 \mathrm{~m}$ above sea level.

The area is situated within the tropical rain forest region, with a climate characterized by dry and wet seasons. Annual rainfall ranges between 100 and $1500 \mathrm{~mm}$, with average wet days of about 100 . The annual temperature varies between $18^{\circ} \mathrm{C}$ to $34^{\circ} \mathrm{C}$.

The study area lies within the basement complex of south-western Nigeria and is characterized by migmatite gneiss and pelitic schist with quartzite layers (Rahaman 1976), (Figure 2). The local geological mapping of the study area revealed that the area is underlain mainly by quartzite. Borehole data and geoelectric curves obtained from the study area revealed that the relative overburden thickness within the study area ranges between $22 \mathrm{~m}$ and $28 \mathrm{~m}$.

The basement complex rocks are poor aquifers as they are characterized by low porosity and negligible permeability, resulting from their crystalline nature, thus availability of groundwater resource in such areas can only be attributed to the development of secondary porosity and permeability resulting from weathering and fracturing.

According to Oyawoye (1972) and Rahaman (1976) the identified lithological units in south western Nigeria are: Migmatite and granite gneisses, Quartzites slightly migmatised to unmigmatised metasedimentary schist and meta-igneous rocks, charnockitic, grabbroic and dioritic rocks, and the members of the older granite suites mainly granites, granodiorites and syenites.

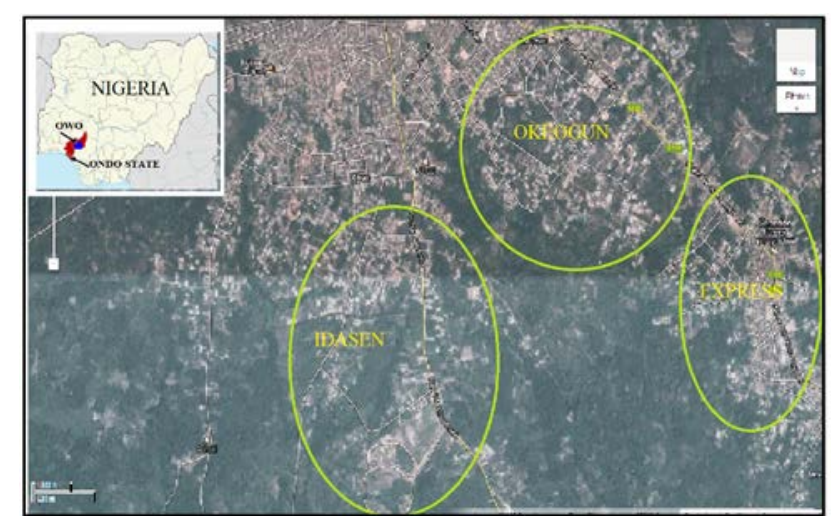

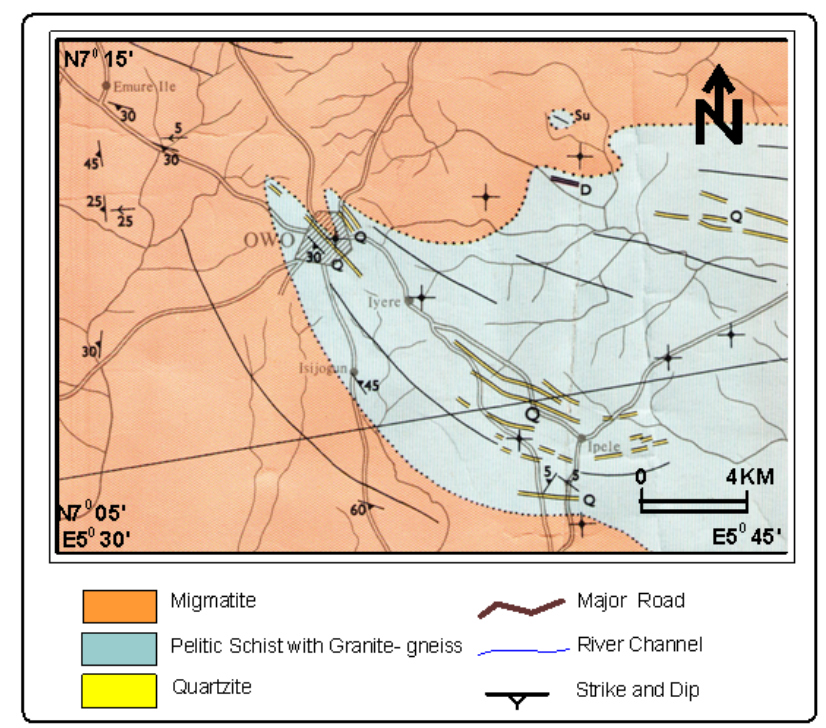

Figure 2. Geology Map Of The Study area adapted from Nigerian Geological Survey Agency

\section{Methodology, Data Acquisition and Interpretation}

The geophysical resistivity data was acquired with the R-50 d.c. resistivity meter which contain both the transmitter unit, through which current enters the ground and the receiver unit, through which the resultant potential difference is recorded. Other materials include: two metallic current and two potential electrodes, two black coloured connecting cable for current and two blue coloured cable for potential electrodes, two reels of calibrated rope, hammer for driving the electrodes in the ground, compass for finding the orientation of the traverses, cutlass for cutting traverses and data sheet for recording the field data. The Schlumberger array was adopted.

The electrode spread of $A B / 2$ was varied from 1 to a maximum of $150 \mathrm{~m}$. The expected depth of investigation was $(D)=0.125 \mathrm{~L}$, where $\mathrm{L}=\mathrm{AB} / 2$ and $\mathrm{AB}$ the current electrode separation. Sounding resistivity against $A B / 2$ or half the spread length on a bi-log paper. Ground resistance (R) measurements were recorded with the R-50 d.c resistivity meter. The electrical resistances obtained were multiplied by the corresponding geometric factor $(k)$ for each electrode separation to obtain the apparent resistivity $(\mathrm{r}=\mathrm{kR})$ in ohm-meter.

The models obtained from the calculations above were used for computer iteration to obtain the true resisitivity and thickness of the layers. Computer-generated curves were compared with corresponding field curves by using a computer program "Resist” version 1.0. The software was further used for both computer iteration and modeling. Computer iteration of between 1 - 29 were carried out to reduce errors to a desired limit (3.0 on the average) and to improve the goodness of fit. Areas where the overburden thickness was greater than $25 \mathrm{~m}$ and are of low clay content (resistivity above $100 \Omega$-m) were considered zones of high groundwater potential while those within 10 and $25 \mathrm{~m}$ are zones of medium groundwater potential and less than $10 \mathrm{~m}$ are of low groundwater potential. 
A total of 32 VES locations across 3 sections were spread over the study area (Figure 2). The processed data were interpreted, resulting curve types were assessed, existing subsurface lithologic units were established, and the geoelectric properties of the various subsurface layers were used in delineating the aquiferous units in the study area. The results are presented in the form of table (Table 1), geoelectric curves (Figure 3) and sections (Figure 4).

Six different subsurface lithologic sequences were established namely; lateritic topsoil, clay, sand, quartzite, weathered/fractured basement and, basement. The curve types ranges between simple $\mathrm{K}, \mathrm{H}, \mathrm{HA}, \mathrm{HK}, \mathrm{KH}$ to complex KHA, HKH and KHK. The topsoil, clay, sand and weathered basement materials are characterised with relatively low resistivity values while the quartzite ridge materials and crystalline basement are typified with high resistivity values. A summary of the results of interpretation, on which the following findings were hinged, is shown in Table 1.

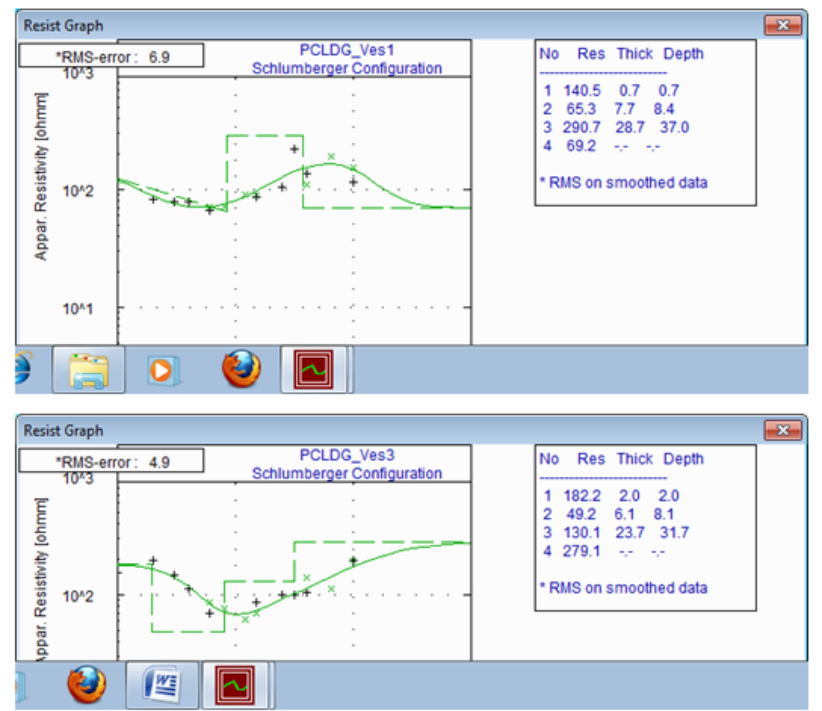

Figure 3. Typical Geoelectric curves from data interpretations

Table 1. Correlation Table of the Study Area Showing the Different Average Lithologic Units Parameters

\begin{tabular}{|c|c|c|c|c|}
\hline SECTION & & IDASEN & OKEOGUN & EXPRESS \\
\hline LITHOLOGY & AVERAGE & & & \\
\hline \multirow{2}{*}{ TOP SOIL } & THICKNESS(M) & 2 & 2 & 2 \\
\hline & $\Omega \mathrm{m}$ & 180 & 269 & 210 \\
\hline \multirow{2}{*}{ CLAY } & THICKNESS(M) & - & 3 & 9 \\
\hline & $\Omega m$ & - & 14 & 54 \\
\hline \multirow{2}{*}{ SAND } & THICKNESS(M) & 13 & 2 & 19 \\
\hline & $\Omega \mathrm{m}$ & 102 & 128 & 114 \\
\hline \multirow{2}{*}{ QUARTZITE } & THICKNESS & 8 & 5 & 20 \\
\hline & $\Omega \mathrm{m}$ & 422 & 420 & 991 \\
\hline \multirow{2}{*}{ WEATHERED/FRACTURED BASEMENT } & THICKNESS(M) & 11 & 15 & 10 \\
\hline & $\Omega m$ & 114 & 87 & 57 \\
\hline BASEMENT & $\Omega \mathrm{m}$ & 400 & 854 & 381 \\
\hline $\begin{array}{l}\text { 4.1. Geoelectric Units } \\
\text { The geoelectric sections (Figure 4) shov } \\
\text { variations of resistivity and thickness val }\end{array}$ & \multicolumn{4}{|c|}{$\begin{array}{l}\text { Quartzite was encountered across the sections and the } \\
\text { average resistivity and thickness values for the quartzit } \\
\text { are, } 611 \Omega \mathrm{m} \text { and } 11 \mathrm{~m} \text { respectively. }\end{array}$} \\
\hline
\end{tabular}
within the depth penetrated in the study area at the indicated sections. Generally, the sections revealed six subsurface layers: top-soil, clay, sand, Quartzite, weathered/fractured basement and the presumed fresh basement.

\subsection{Topsoil}

The topsoil thickness is relatively thin along these sections. The average resistivity and thickness values for the topsoil are $220 \Omega \mathrm{m}$ and $2 \mathrm{~m}$ respectively, which indicated that the predominant composition of the topsoil is lateritic clay.

\subsection{Clay}

Clay was encountered in two of the sections and the average resistivity and thickness values for the clay are, 34 $\Omega \mathrm{m}$ and $6 \mathrm{~m}$ respectively.

\subsection{Sand}

Sand was encountered across the three sections and the average resistivity and thickness values for the sand are, $115 \Omega \mathrm{m}$ and $11 \mathrm{~m}$ respectively.

\subsection{Quartzite}

\subsection{Weathered Layer/Fractured Layer}

Weathered/fractured basement was encountered across the sections and the average resistivity and thickness values for the weathered/fractured basement are, $86 \Omega \mathrm{m}$ and $12 \mathrm{~m}$ respectively thus indicating that the material composition is largely clay, sandy clay and clayey sand or high degree of fracture and/or water saturation.

\subsection{Basement}

The basement is the fresh bedrock and is the last layer. It is relatively deep in the study area, it was encountered across the three sections and the average resistivity and depth values to the top of basement are, $628 \Omega \mathrm{m}$, and 24 $\mathrm{m}$ respectively. The resistivity values are so high because of its crystalline nature. It is of infinite thickness where it is the last observable layer.

\subsection{Overburden}

The overburden in assumed to include all materials above the presumably fresh basement. The depth to the bedrock varies from 9.0 to $34.0 \mathrm{~m}$ and the average depth to the bedrock is $24 \mathrm{~m}$ (Table 1 and Figure 4). Overburden thickness was established across the three sections and the 
average thickness value is $24 \mathrm{~m}$. Generally, areas with thick overburden and low percentage of clay in which intergranular flow is dominant are known to have high groundwater potential particularly in basement complex terrain (Okhue and Olorunfemi, 1991).

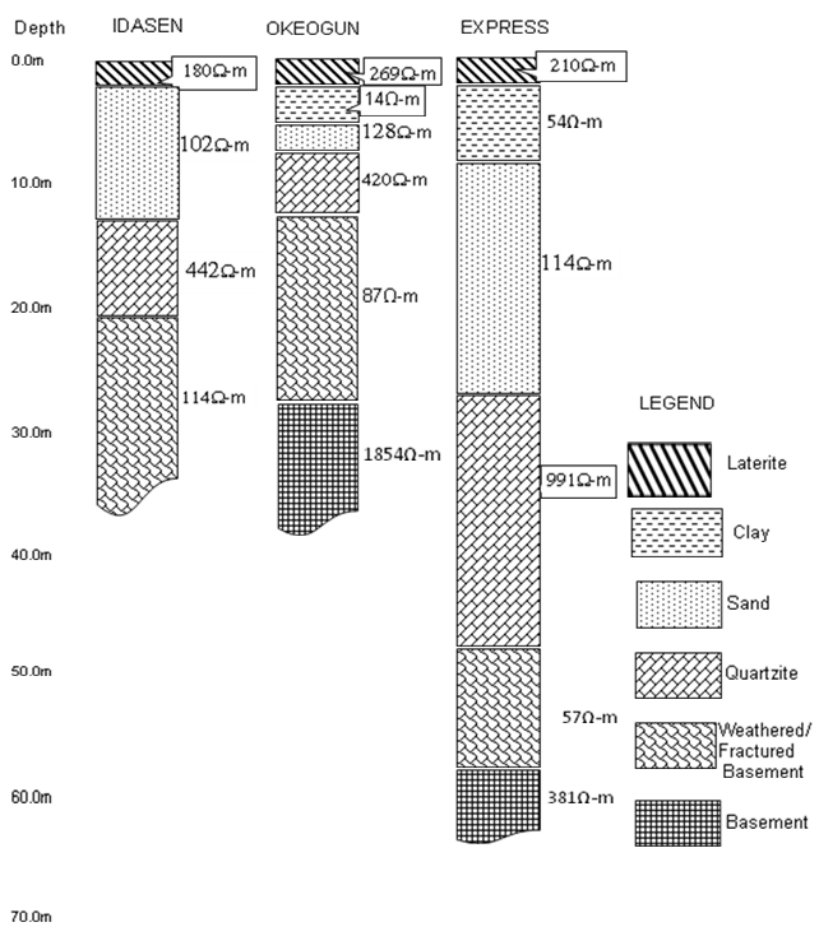

Figure 4. Typical Geoelectric Section across the study area

\section{Evaluation of Groundwater Potential}

Given the average resistivity values and thicknesses of the sand, weathered/fractured layers and the overburden thickness, (Table 1 and Figure 4), the study area is highly productive. The combination of overburden materials with the weathered/fractured basement constitutes aquiferous units within the study area although the sand and weathered/fractured basement units are largely responsible for the groundwater potential.

Observed thickness and nature of the weathered layer are important parameters in the groundwater potential evaluation of a basement complex terrain (Clerk, 1985; Bala and Ike, 2001). A layer is regarded as a significant water-bearing layer (Bala and Ike 2001) if significantly thick and the resistivity parameters suggest saturated conditions.

\section{Conclusions}

In this study, the groundwater potential of Northeastern part of Owo, southwestern Nigeria was evaluated using 32 Schlumberger vertical electrical soundings (VES). The curve types range between simple K, H, HA, HK, KH to complex KHA, HKH and KHK. The computer assisted sounding interpretation revealed six different subsurface lithologic sequences namely; lateritic topsoil, clay, sand, quartzite, weathered/fractured basement and, basement. The topsoil, sand, weathered/fractured basement constitute the aquiferious units.

An average thickness value of $22 \mathrm{~m}$ and resisitivity of $212 \Omega \mathrm{m}$ of aquiferous unit and of low clay content is suggestive of a moderate groundwater potential. basement materials are characterised with relatively low resistivity values while the quartzite ridge and basement materials are typified The combination of overburden materials with the weathered/fractured basement constitutes aquiferous units within the study area although the sand and weathered basement units are largely responsible for the groundwater potential. The yield of the weathered basement material is dependent on the amount of the clay content. The higher the clay content, the lower the groundwater yield. The topsoil has limited hydrologic significance.

The groundwater potential rating of the area is considered high. There is need for proper completion of borehole(s) and extensive storage and reticulation facilities will be required. An average depth of $40 \mathrm{~m}$ to 50 $\mathrm{m}$ is recommended for boreholes in this area.

\section{References}

[1] Bala AE, Ike EC (2001). The aquifer of the crystalline basement rocks In Gusau area, NW Nigeria. J. Min. Geol. 37 (2): 177-184.

[2] Clerk L (1985). Groundwater Abstraction from Basement Complex Areas of Africa. J. Eng. Geol., London 18: 25-34.

[3] Idornigie AI, Olorunfemi MO (1992). A Geoelectric mapping of the Basement Structures in the central part of the Bida Basin and its Hydrogeological Implication. J. Min. Geol., 28 (1): 93-103.

[4] Olayinka AI, Olorunfemi MO (1992). Determination of geoelectrical Characteristic in Okene Area and implication for boreholes setting. J. Min. Geol., 28: 403-412.

[5] Olorunfemi MO, Fasuyi SA (1993). Aqufier types and geoelectric/hydrogeologic characteristics of part of central basement terrain of Nigeria (Niger State). J. Africa Earth Sci., 16 (3): 309-317.

[6] Olorunfemi MO, Olorunniwo MA (1985). Parameters and aquifer characteristics of some parts of SW. Nigeria Geologic Applica E. Hydrogeological, XX Part 1, pp. 99-109.

[7] Rahaman MA (1989). Review of the basement geology of SW Nigeria: In Geology of Nigeria (Kogbe CA Ed.). Elizabeth Publishing. Co. Nigeria. pp. 41-58.

[8] Anhaeusser, C. R, 1969. A Resappraisal of some aspects of Precambrian shield geology bull, Geo. Soc, Amer., Vol. 80, pp 2175-2200.

[9] Grant, F. S., West, G. F, 1965. Interpretation theory in Applied Geophysics. New York, McGraw-Hill

[10] Olorunfemi M. D. \& Olayinka A. I. (1992): Alteration of Geoelectric in Okene are and Implication for Borehole Sitting. Journal of Mining and Geology, pp. 403-411.

[11] Olorunfemi M. O. (1990): The Hydrogeological Implication of Topographic Variation with Overburden Thickness in Basement Complex. Area of SW Nigeria. Journal of Mining and Geology. Vol. 26, No. 1.

[12] Olorunfemi M. O. \& Oloruniwo M. A. (1985): Geoelectric Parameters and Aquifer Characteristics of Some Part of SW Nigeria. Journal of Mining and Geology.

[13] Rahaman M. A. (1976): Review of the Basement Geology of SW Nigeria in Geology of Nigeria. Elizabithan Publishing Company, Nigeria. pp. 41-58. 